(C) Group of authors, 2018

UDC 612.128:616.379-008:612.393.1

DOI - https://doi.org/10.14300/mnnc.2018.13092

ISSN - 2073-8137

\title{
CHARACTERIZATION OF THE METABOLIC DISORDERS IN RATS WITH ALLOXAN-INDUCED DIABETES AND CHRONIC ALCOHOLIC INTOXICATION
}

\author{
Bykov I. M. 1, Popov K. A. 1, Berberidy H. P. 1, Tsymbalyuk I. Yu. 1, \\ Ermakova G. A. 1, Pavlyuchenko I. I. 1, Storozhuk P. G. 1, Ovsyannikov V. G. ${ }^{2}$ \\ ${ }^{1}$ Kuban State Medical University, Krasnodar, Russian Federation \\ 2 Rostov State Medical University, Rostov-on-Don, Russian Federation

\section{ОСОБЕННОСТИ МЕТАБОАИЧЕСКИХ НАРУШЕНИЙ У КРЫС С ААМОКСАНОВЫМ АИАБЕТОМ, РАЗВИВШИМСЯ НА ФОНЕ ХРОНИЧЕСКОЙ ААКОГОАЬНОЙ ИНТОКСИКАЦИИ}

\author{
И. М. Быков ${ }^{1}$, К. А. Попов ${ }^{1}$, Х. П. БербериАи ${ }^{1}$, И. Ю. Цымбалюк ${ }^{1}$, \\ Г. А. Ермакова ' , И. И. ПавАюченко ', П. Г. Сторожук ', В. Г. Овсянников ${ }^{2}$
${ }^{1}$ Кубанский госуАарственный МеАицинский университет, КрасноАар, Российская ФеАерация
2 Ростовский госУАарственный МеАицинский Университет, Ростов-на-Аону, Российская ФеАерация

\begin{abstract}
We investigated the metabolic disorders in rats with alloxan-induced diabetes and chronic alcoholic intoxication. Rats were divided into four groups: the first group was untreated controls, the second group was administered alloxan to induce diabetes, the third consumed ethanol for 2 months, and the fourth group consumed ethanol for 2 months and were injected with alloxan half way through this period. Plasma glucose concentrations in rats with both alcoholic intoxication and alloxaninduced diabetes were $22 \%$ higher than in those with alloxan-induced diabetes alone. Plasma ALT activity was 1.7 and 2.2 times higher in rats in groups 3 and 4, respectively, than in control rats. Rats in group 4 showed a $30 \%$ higher GR activity and $29 \%$ and $20 \%$ reductions in CAT and SOD activities in erythrocytes, respectively, versus controls. In addition, the concentration of GR in erythrocytes was a mean $31 \%$ lower in rats in groups 2-4 than in controls. These data reveal more severe disruption of carbohydrate metabolism and a more severe imbalance in the antioxidant system in rats with diabetes mellitus if they have already been subjected to chronic alcohol intoxication.
\end{abstract}

Keywords: alloxan diabetes, alcohol, oxidative stress, antioxidant system

Исследование особенностей углеводного обмена, цитолиза гепатоцитов и антиоксидантной системы при экспериментальном диабете на фоне хронической алкоголизации проведено на белых крысах, разделенных на 4 группы. Первую группу составили интактные животные. Группу 2 составили животные с моделированием аллоксанового диабета. Животные 3-й группы подвергались алкоголизации в течение 2 месяцев. Группу 4 составили крысы, которым по той же схеме проводили алкоголизацию, но спустя месяц начала эксперимента вводили аллоксан. В ходе исследований было установлено, что концентрация глюкозы плазмы крови при сочетанном течении алкогольной интоксикации и аллоксанового диабета превышала значения аналогичного показателя животных только с диабетом на $22 \%$. Исследование активности АЛТ показало значительное ее увеличение в плазме крови животных 3-4-й групп по сравнению с контролем в 1,7-2,2 раза. Эритроциты крыс 4-й группы характеризовались увеличенными значениями активности глутатионредуктазы на 30 \%, сниженной на 29 и 20 \% соответственно каталазной и супероксиддисмутазной активностью. Концентрация восстановленного глутатиона в эритроцитах была снижена на $31 \%$ у животных всех групп. Представленные данные отражают более тяжелое течение нарушений углеводного обмена и дисбаланса антиоксидантной системы при развитии экспериментального диабета на фоне хронической алкоголизации.

Ключевые слова: алоксановый диабет, алкоголь, окислительный стресс, антиоксидантная система

For citation: Bykov I. M., Popov K. A., Berberidy H. P., Tsymbalyuk I. Yu., Ermakova G. A., Pavlyuchenko I. I., Storozhuk P. G., Ovsyannikov V. G. CHARACTERIZATION OF THE METABOLIC DISORDERS IN RATS WITH ALLOXAN-INDUCED DIABETES AND CHRONIC ALCOHOLIC INTOXICATION. Medical News of North Caucasus. 2018;13(3):511-515. DOI - https://doi.org/10.14300/mnnc.2018.13092

Для цитирования: Быков И. М., Попов К. А., Бербериди Х. П., Цымбалюк И. Ю., Ермакова Г. А., Павлюченко И. И., СТОрОЖУК П. Г., ОВСЯНИКОВ В. Г. ОСОБЕННОСТИ МЕТАБОЛИЧЕСКИХ НАРУШЕНИЙ У КРЫС С АЛЛОКСАНОВЫМ ДИАБЕТОМ, РАЗВИВШИМСЯ НА ФОНЕ ХРОНИЧЕСКОЙ АЛКОГОЛЬНОЙ ИНТОКСИКАЦИИ. МеДИЦИНСКИЙ вестНИК СЕВЕрНОГО Кавказа. 2018;13(3):511-515. DOI - https://doi.org/10.14300/mnnc.2018.13092 
ALT - Alanine Transaminase

AST - Aspartate Transaminase

CAT - Catalase

DM - Diabetes Mellitus
GPO - Glutathione Peroxidase

GR -Glutathione Reductase

KubSMU - Kuban State Medical University

SOD -Superoxide Dismutase
0 ne of the most urgent medical and social concerns in modern health care is alcoholism, which can be accompanied by the development of a variety of changes consistent with systemic intoxication [1]. Among the multiple visceral pathologies induced by alcoholism that influence quality of life and lifespan, the most severe occurs in the liver. The liver plays an important role in ethanol metabolism, which can lead to the preferential accumulation of ethanol and the toxic products of its oxidation by alcohol dehydrogenase, including acetaldehyde and acetic acid [2]. Thus, the liver can be considered to be the principal site of the toxic effects of ethanol and it manifests the principal defects in the pathogenesis of alcoholism. However, the liver is also the main organ responsible for glucose and energy homeostasis. One of the key defects caused by the chronic alcoholic intoxication that develops during the first 2-4 months is hypoglycemia, which probably occurs as a result of the suppression of gluconeogenesis and glycogenesis in the liver [3].

According to a previous study [4], chronic alcoholic intoxication is accompanied by diabetes mellitus (DM) in $8-10 \%$ of patients. Considering that hypoglycemia develops following temporary alcoholic intoxication, whereas hyperglycemia is the main problem in DM, the effects of each on carbohydrate metabolism are clearly different in these two conditions. Therefore, the molecular mechanisms involved in the effects of alcoholization and DM together are of great interest. A number of previous studies have shown that chronic alcoholization in patients suffering from type II DM not only inhibits insulin secretion but also aggravates insulin resistance in tissues, potentiating hyperglycemia and upregulating non-fermented glycation of proteins [5-6]. One of the main pathophysiological links between DM and alcoholism is oxidative stress, which may aggravate the metabolic disorders involved in these diseases.

It is of note that in most studies in laboratory animals a model of DM is created and alcohol is then only administered for a matter of days or a month after this. Such models have a number of limitations. Firstly, animals with alloxan or streptozotocin-induced diabetes have a short lifespan, making it difficult to superimpose chronic alcoholic intoxication. Secondly, to more accurately model the real-life situation it would be more appropriate to induce DM against a background of pre-existing chronic alcoholic intoxication, because alcohol addiction typically develops at a young age.

We aimed to characterize the metabolic disorder that develops in rats with experimentally induced DM superimposed upon pre-existing chronic alcoholic intoxication.

Material and Methods. The study was performed using 80 male rats initiallyweighing $210-240 \mathrm{~g}$. The testanimals were housed in the vivarium of the KubSMU. The study was carried out in accordance with the «Rules of the European convention on the protection of vertebrate animals» (Strasbourg, 1986) and was approved by the ethics committee of the KubSMU (report № 54 of October 11 $11^{\text {th }}$ 2017).

The rats were divided into four groups of 20. Group 2(DM group) had DM induced by a single intraperitoneal injection of alloxan monohydrate ( $15 \mathrm{mg} / 100 \mathrm{~g}$ body mass) after a day of fasting. Group 3 (A group) underwent alcoholization for 2 months. During the first week these rats were given
$10 \%$ ethanol in place of water, during the second week $20 \%$, then $30 \%$ for the remaining period. Group 4 (A+DM group) underwent alcoholization as described above but 1 month after ethanol consumption commenced they were also injected with alloxan as described above. Group 1 (control) were housed under the same conditions but were not given ethanol and were injected with $1-\mathrm{ml}$ vehicle intraperitoneally in place of alloxan. One month after the alloxan injection rats were anesthetized by intramuscular injection of $10 \mathrm{mg} / \mathrm{kg}$ tiletamine and zolazepam (Zoletil 100, Virbac, France) and their blood was sampled for further laboratory investigation.

Plasmaglucoseconcentration, alanineaminotransferase (ALT) and aspartate aminotransferase (AST) activity were determined using kits (Vital Development Corporation, Russia). To evaluate the status of the antioxidant system the activities of superoxide dismutase (SOD), catalase (CAT), glutathione peroxidase (GPO), and glutathione reductase (GR) were determined. CAT activity was determined by measuring the recycling speed of hydrogen peroxide, measured using the absorption of light at $260 \mathrm{~nm}$ [7]. SOD activity was determined using the deceleration stage of quercetin autooxidation [8]. GPO activity was determined by the rate of oxidation of glutathione during its reaction with tert-butyl hydroperoxide [7]. GR activity was determined by measuring the consumption of NADPH during the restoration of the oxidized form of glutathione [7]. The content of reduced glutathione (GSH) in erythrocytes was determined by quantifying its reaction with dithiobisnitrobenzoic acid after deproteinization using sulfosalicylic acid [7].

The oxidative modification of proteins was evaluated by measuring the amount of bityrosine remaining in the blood and the autofluorescence of tryptophan in proteins. The evaluation of the autofluorescence of tryptophanyls was carried out after the dilution of the blood plasma to contain $0.5 \mathrm{mg} / \mathrm{ml}$ protein using an excitation wavelength of $280 \mathrm{~nm}$ and an emission wavelength of $330 \mathrm{~nm}$. The determination of bityrosine content was performed using a fluorometric method involving an excitation wavelength of $325 \mathrm{~nm}$ and an emission wavelength of $418 \mathrm{~nm}$ [9]. The content of glycation products in the blood plasma was measured fluorometrically using an excitation wavelength of $370 \mathrm{~nm}$ and an emission wavelength of $404 \mathrm{~nm}$ [10]. Measurement of fluorescence intensity was performed using a CM2203 spectrofluorometer (SOLAR, Belarus).

Data processing. Stat plus LE was used to analyze the data. They are presented as median (Me), $25^{\text {th }}$, and $75^{\text {th }}$ percentiles $(\mathrm{p} 0,25 / \mathrm{p} 0,75)$ and were analyzed using the Mann - Whitney U-test. $\mathrm{p}<0.05$ was considered to represent statistical significance.

Results and Discussion. The rates of mortality in the first 2-4 days after alloxan injection in rats in Groups 2 and 4 were $28 \%$ and $32 \%$, respectively, which is typical for this experimental model [11]. The plasma glucose concentration in rats with alloxan-induced diabetes increased by $66.4 \%$ in the first month after the administration of alloxan (Table 1). In animals that underwent alcoholization for 2 months plasma glucose was similar to that of control rats. It is well established that hypoglycemia occurs following chronic alcoholization, but in a previous study [5] in which the plasma glucose concentrations had halved, the rats had been given ethanol for more than 16 weeks. However, in another study [3] gavage of ethanol for 14 days caused slight hyperglycemia (29\% increase), although by the 29th day, glycemia had 
returned to normal. Finally, in a third study [12] 2-month alcoholization caused a non-significant lowering of plasma glucose concentration. Thus, our data are consistent with some of the findings of earlier studies. The plasma glucose concentration of rats with alloxan-induced diabetes was two-fold higher than that of the control group and was $21.5 \%$ higher than that of rats in Group 2.

Table 1

Plasma glucose and aminotransferase activity in rats with alloxan-induced diabetes, chronic alcoholization, or both

\begin{tabular}{|l|c|c|c|}
\hline \multirow{2}{*}{$\begin{array}{c}\text { Group, } \\
\text { NN }\end{array}$} & $\begin{array}{c}|c| \\
\text { Glucose, } \\
\text { mmol/I }\end{array}$ & ALT, units/I & AST, units/I \\
\cline { 2 - 4 } $\begin{array}{l}\text { 1 (Control) } \\
\text { group }\end{array}$ & $\begin{array}{c}6.40 \\
(5.90 / 6.91)\end{array}$ & $\begin{array}{c}23.51 \\
(19.41 / 24.52)\end{array}$ & $\begin{array}{c}44.64 \\
(42.89 / 47.93)\end{array}$ \\
\hline $\begin{array}{l}2 \text { (DM) } \\
\text { group }\end{array}$ & $\begin{array}{c}10.65^{*} \\
(10.26 / 11.56)\end{array}$ & $\begin{array}{c}23.40 \\
(22.00 / 24.33)\end{array}$ & $\begin{array}{c}47.55 \\
(44.17 / 50.46)\end{array}$ \\
\hline $\begin{array}{l}3(\mathrm{~A}) \\
\text { group }\end{array}$ & $\begin{array}{c}6.76 \\
(6.08 / 7.02)\end{array}$ & $\begin{array}{c}40.19 * \\
(35.83 / 48.9)\end{array}$ & $\begin{array}{c}45.28 \\
(40.33 / 47.61)\end{array}$ \\
\hline $\begin{array}{l}\text { 4 (A+DM) } \\
\text { group }\end{array}$ & $\begin{array}{c}12.93^{*} \text { (12 } \\
(12.19 / 14.68)\end{array}$ & $\begin{array}{c}50.70 * \wedge \\
(42.60 / 65.62)\end{array}$ & $\begin{array}{c}49.30 \\
(47.84 / 55.54)\end{array}$ \\
\hline
\end{tabular}

Note: * - statistically significant difference $(\mathrm{p}<0.05)$ versus Group $1 ;{ }^{\wedge}$ - statistically significant difference $(p<0.05)$ between Groups 2 and 4; \# - statistically significant difference $(p<0.05)$ between Groups 3 and 4.

Measurement of plasma hepatic transaminase activities demonstrated significantly higher ALT activity in Groups 3 and 4 (1.7 and 2.2 times control levels, respectively; Table 1 ), but no differences between these groups. Plasma AST activity in Groups 2-4 was no different from control values. However, such changes in markers of hepatocyte cytolysis are characteristic of a chronic hepatic disorder.

Study of the activity of antioxidant enzymes showed lower levels of SOD and CAT activity in erythrocytes in Groups 2-4 (Table 2). SOD activity in rats in Groups 2, 3, and 4 was $10.5 \%, 13 \%$, and $29.5 \%$ lower than in control rats, respectively. CAT activity in erythrocytes from animals in Groups 2 and 3 was $31 \%$ and $43 \%$ lower than in control rats, indicating a decrease in the resistance of the rats to cellular peroxidation due to the formation of active forms of oxygen, meaning that there is a greater risk of oxidative damage to cellular structures [13]. However, CAT activity in erythrocytes from rats in Group 4 showed a smaller (20\%) difference from control rats. Nevertheless, relative insufficiency of SOD activity in the erythrocytes rats with alloxan-induced diabetes and 2-month alcoholization implies impaired inactivation of the superoxide anion and thus the presence of oxidative stress, which represents an adverse prognostic factor [14].

Table 2

Activity of enzymes involved in antioxidant protection in erythrocytes from rats with alloxan-induced diabetes, chronic alcoholization, or both

\begin{tabular}{|l|c|c|}
\hline \multirow{2}{*}{$\begin{array}{c}\text { Group } \\
\text { NN }\end{array}$} & \multicolumn{2}{|c|}{ Indices } \\
\cline { 2 - 3 } & SOD, con. un. & CAT, mmol/I×min \\
\hline $\begin{array}{l}\text { 1 (Control) } \\
\text { group }\end{array}$ & $65.22(62.89 / 67.05)$ & $16.24(15.84 / 20.85)$ \\
\hline $\begin{array}{l}2(\mathrm{DM}) \\
\text { group }\end{array}$ & $56.77(56.02 / 58.00) *$ & $9.42(7.96 / 10.74) *$ \\
\hline $\begin{array}{l}3(\mathrm{~A}) \\
\text { group }\end{array}$ & $58.40(56.7 / 62.7) *$ & $11.24(10.54 / 15.02) *$ \\
\hline $\begin{array}{l}4(\mathrm{~A}+\mathrm{DM}) \\
\text { group }\end{array}$ & $46.07(45.14 / 50.10) * \wedge \#$ & $13.08(11.39 / 15.25) * \wedge$ \\
\hline
\end{tabular}

Note: * - statistically significant difference $(p<0.05)$ versus Group $1 ;{ }^{\wedge}$ - statistically significant difference $(p<0.05)$ between Groups 2 and 4 ; \# - statistically significant difference $(p<0.05)$ between Groups 3 and 4.
The enzymes of glutathione metabolism neutralize secondary and tertiary radicals and regenerate other antioxidants, representing a second line of defense against free radicals and reactive molecules, and a more adaptive mechanism. Increases in activity of both GPO and GR during the initial stages of development of the pathological process and prolonged high levels of activity have been demonstrated in other similar studies [15-17]. Measurement of the activity of these enzymes of glutathione metabolism in animals with alloxaninduced diabetes revealed respectively $68 \%$ and $37 \%$ higher activity levels of GPO and GR (Table 3 ). In rats that had undergone chronic alcoholization the GPO activity was $50 \%$ higher and the GR activity was $88 \%$ higher than controls. The erythrocytes of rats in Group 4 were characterized by $30 \%$ higher GR activity, but there was no difference from controls in their GPO activity. This may imply a decompensation of the thiol link in the antioxidant system of animals in Group 4. The concentration of reduced glutathione in the erythrocytes was lower in Groups 2-4 than controls by a mean 31\%, but there were no significant differences between the three experimental groups.

Indices of the metabolic state of glutathione in erythrocytes of rats with alloxan diabetes, chronic alcoholization, or both

\begin{tabular}{|c|c|c|c|}
\hline \multirow{2}{*}{$\underset{\text { NN }}{\text { Group, }}$} & \multicolumn{3}{|c|}{ Indices } \\
\hline & $\begin{array}{c}\mathrm{GPO}, \\
\mu \mathrm{mol} / / \times \min \end{array}$ & $\begin{array}{c}\mathrm{GR}, \\
\mu \mathrm{mol} / \mathrm{I} \times \min \end{array}$ & $\begin{array}{c}\mathrm{GSH} \\
\mu \mathrm{mol} / \mathrm{ml}\end{array}$ \\
\hline $\begin{array}{l}1 \\
\text { (Control) } \\
\text { group }\end{array}$ & $\begin{array}{c}330.2 \\
(300.55 / \\
358.69) \\
\end{array}$ & $\begin{array}{c}742.23 \\
(650.30 / \\
800.25) \\
\end{array}$ & $\begin{array}{c}2,44 \\
(2.29 / \\
2.62) \\
\end{array}$ \\
\hline $\begin{array}{l}2 \\
\text { (DM) } \\
\text { group } \\
\end{array}$ & $\begin{array}{c}553.30 * \\
(502.10 / \\
585.96) \\
\end{array}$ & $\begin{array}{c}1,021.03 * \\
(911.80 / \\
1,131.57)\end{array}$ & $\begin{array}{c}1.68 * \\
(1.61 / \\
1.74) \\
\end{array}$ \\
\hline \begin{tabular}{|l}
3 \\
$(A)$ \\
group \\
\end{tabular} & $\begin{array}{c}496.59 * \\
(423.14 / \\
507.09) \\
\end{array}$ & $\begin{array}{c}1,392,1 * \\
(1,297.9 / \\
1,411.5) \\
\end{array}$ & $\begin{array}{l}1.66 * \\
(1.51 / \\
2.06) \\
\end{array}$ \\
\hline $\begin{array}{l}4 \\
(A+D M) \\
\text { group }\end{array}$ & $\begin{array}{c}347.99 \wedge \# \\
(328.69 / \\
414.68)\end{array}$ & $\begin{array}{c}961.9 * \# \\
(889.14 / \\
1,124.81)\end{array}$ & $\begin{array}{l}1.69 * \\
(1.63 / \\
2.14)\end{array}$ \\
\hline
\end{tabular}

Note: * - statistically significant difference $(p<0.05)$ versus Group $1 ;{ }^{\wedge}$ - statistically significant difference $(p<0.05)$ between Groups 2 and 4 ; \# - statistically significant difference $(p<0.05)$ between Groups 3 and 4.

Measurement of the fluorescence indices in the plasma revealed a larger quantity of products of nonfermented glycation of proteins in rats with alloxan diabetes alone and in those that had also been subjected to chronic alcoholic intoxication. However, in Group 2 this was $69 \%$ higher, while in Group 4 it was only $33 \%$ higher than in controls. The bityrosine residue content was higher than in controls in all the experimental groups by $10-20 \%$. Bityrosine is generated by the monoelectronic oxidation of the tyrosine residues of protein molecules, with the fusing of two such residues. This is a predictable product of protein oxidation that is suitable for use as a marker of oxidative damage because it has a long half-life and is accumulated in the body [18]. The fluorescence of tryptophan residues in protein molecules in the blood plasma was 26-30.5\% lower in Groups 2-4 than in controls. The fluorescence of tryptophan residues in proteins depends on their surroundings; therefore, this provides confirmation of oxidative changes in molecules or the effects of endotoxins (Table 4). 
Plasma concentrations of products of glycation and oxidative modification of proteins in rats with alloxan diabetes, chronic alcoholization, or both

\begin{tabular}{|c|c|c|c|}
\hline \multirow[b]{2}{*}{$\underset{\text { NN }}{\text { Group, }}$} & \multicolumn{3}{|c|}{ Indices } \\
\hline & PGP, conv. units & $\begin{array}{l}\text { Bityrosine, } \\
\text { conv. units }\end{array}$ & $\begin{array}{c}\text { Fluorescence } \\
\text { of } \\
\text { tryptophanyls, } \\
\text { conv. units }\end{array}$ \\
\hline $\begin{array}{l}1 \text { (Control) } \\
\text { group }\end{array}$ & $\begin{array}{c}0.80 \\
(0.76 / 0.90)\end{array}$ & $\begin{array}{c}1.61 \\
(1.50 / 1.68)\end{array}$ & $\begin{array}{c}27.2 \\
(27.0 / 28.6)\end{array}$ \\
\hline $\begin{array}{l}2 \text { (DM) } \\
\text { group }\end{array}$ & $\begin{array}{c}1.35 \\
(1.23 / 1.44)^{*}\end{array}$ & $\begin{array}{c}1.93 \\
(1.83 / 2.05)^{*}\end{array}$ & $\begin{array}{c}18.9 \\
(18.45 / 19.35)^{*}\end{array}$ \\
\hline $\begin{array}{l}3(\mathrm{~A}) \\
\text { group }\end{array}$ & $\begin{array}{c}0.70 \\
(0.68 / 0.82) \\
\end{array}$ & $\begin{array}{c}1.70 \\
(1.64 / 1.77) \\
\end{array}$ & $\begin{array}{c}19.7 \\
(19.6 / 20.3)^{*}\end{array}$ \\
\hline $\begin{array}{l}4(A+D M) \\
\text { group }\end{array}$ & $\begin{array}{c}1.06 \\
(1.00 / 1.15)^{* \wedge \#}\end{array}$ & $\begin{array}{c}1.88 \\
(1.82 / 1.98)^{*}\end{array}$ & $\begin{array}{c}20.0 \\
(19.4 / 20.4)^{*}\end{array}$ \\
\hline
\end{tabular}

Note: * - statistically significant difference $(p<0.05)$ versus Group $1 ;{ }^{\wedge}$ - statistically significant difference $(p<0.05)$ between Groups 2 and 4; \# - statistically significant difference $(p<0.05)$ between Groups 3 and 4.
Conclusions. Our data demonstrate the complex disorders of carbohydrate metabolism when experimental diabetes is induced against a background of chronic alcoholization, involving a number of pathological processes. Interestingly, the quantity of products of nonfermented glycation of plasma proteins in rats that had alloxan-induced diabetes and had undergone chronic alcoholization was lower than in the animals with diabetes alone. This could be the result of the temporary appearance of hyperglycemia in animals consuming ethanol, which could be especially apparent in the early stages of the pathological process. The severity of liver damage in laboratory animals with both diabetes and chronic alcoholic intoxication was no different to that in rats with either diabetes or alcohol intoxication alone, but there was a tendency towards higher ALT activity in the former. There were also effects on the antioxidant system in rats with diabetes and chronic alcoholic intoxication, demonstrated by lower SOD, GPO, and GR activity versus the comparison groups, implying a more pronounced decompensation of the non-specific antioxidant resistant system in these animals.

\section{Disclosures:}

The authors declare no conflict of interest.

Acknowledgements. This work was supported by the State Task of the Ministry of Health Care of the Russian Federation by state assignment (28.01.2015, part 1, chapter 1). We thank Mark Cleasby, PhD, from Edanz Group (www.edanzediting.com/ac) for editing a draft of this manuscript.

\section{References}

1. Shulkin L. M., Kosenko N. A., Kosenko V. G., Ageev M. I., Shulkin M. Z. Clinical overview remission of alcohol dependence. Kubanskij nauchnyj medicinskij vestnik. Kuban scientific medical journal. 2015;2:153-159.

2. Porodenko V. A., Korkhmazov V. T., Travenko E. N. Activity alcoholoxiding fermental systems of the heart, liver and kidney at the sharp poisoning with ethanol. Kubanskij nauchnyj medicinskij vestnik. - Kuban scientific medical journal. 2010;3-4:160-162.

3. Lelevich S. V. Functional state of glucose metabolism in rat liver under chronic alcohol intoxication. Biomeditsinskaya khimiya. - Biomedical Chemistry. 2009;55(6):723-733.

4. Sidorov P. I., Soloviev A. G., Novikova I. The form of alcohol use and diabetes mellitus course. Narkologiya. Narcology. 2002;5:28-33.

5. Bortnikova A., Panova T. Attraction to ethanol in alcoholysed rats and glycemia level, expression of ketosis. Laboratornaya diagnostika. Vostochnaya Evropa. Laboratory diagnostics. Eastern Europe. 2014;9(1):52-61.

6. Indutnyi A. V., Vysokogorsky V. E., Indutnaya L. N. Characteristic manifestations of oxidative stress in alcohol abusers with diabetes mellitus type 2. Biomeditsinskaya khimiya. - Biomedical Chemistry. 2004;50(1):100-103.

7. Karpishchenko A. I. Handbook. Medical Laboratory Technology. Sankt-Petersburg: Intermedika, 2002

8. Kostyuk V. A., Potapovich A. I., Kovaleva Zn. V. A simple and sensitive method of determination of superoxide dismutase activity based on the reaction of quercetin oxidation. Voprosy meditsinskoy khimii. - Problems of Medical Chemistry. 1990;2:88-91.

9. Agrawal A., Rathor R., Suryakumar G. Oxidative protein modification alters proteostasis under acute hypobaric hypoxia in skeletal muscles: a comprehensive in vivo study. Cell Stress Chaperones. 2017;22(3):429-443. https://doi.org/10.1007/s12192-017-0795-8

10. Olar L. E., Stefan R., Berce C., Ciobanu D., Papuc I. The fluorescence identification of advanced glycation end products in streptozotocin - induced diabetic rats' plasma samples. Bulletin UASVM Veterinary Medicine. 2015;72(1):106-109.

https://doi.org/10.15835/buasvmcn-vm:10995
11. Jafarova R. E. Comparative study of different models of alloxan-induced diabetes mellitus. Kazansky meditsinsky zhurnal. - Kazan medical journal. 2013;94(6):915-919.

12. Indutnyi A. V., BykovD. E., Vysokogorsky V. E. Manifestation and pathochemical preconditions of heart damage by combination of chronic alcohol intoxication with diabetes mellitus. Narkologiya. - Narcology. 2009;2:57-61.

13. Bykova N. I., Basov A. A., Melkonyan K. I., Alekseenko E. A., Popov K. A. [et al.] Non-invasive monitoring for local immune and antioxidant resistance in patients with ischemic heart disease and type 2 diabetes. Medical news of North Caucasus. 2016;11(2):147-149.

https://doi.org/10.14300/mnnc.2016.11021

14. Bykov I. M., Basov A. A., Malyshko V. V., Dzhimak S. S., Fedosov S. R. [et al.] Dynamics of the pro-oxidant/ antioxidant system parameters in wound discharge and plasma in experimental purulent wound during its technological liquid phase treatment. Bulletin of Experimental Biology and Medicine. 2017;163(2):268271. https://doi.org/10.1007/s10517-017-3781-3

15. Bykov I. M., Popov K. A., Tsymbalyuk I. Yu., Dzhimak S. S., Shashkov D. I. [et al.] The metabolic correction of the experimental alloxan diabetes by means of the antioxidant remedies. Voprosy pitaniya. - Problems of Nutrition. 2017;86(3):68-76.

16. Radaeva M. V., Vedunova M. V., Kontorshchikova C. N. The state of antioxidative and detoxicative systems in metabolic damage correction by low doses of ozone. Bulletin of the Nizhny Novgorod University. N. I. Lobachevsky. - Vestnik of Lobachevsky University of Nizhni Novgorod. 2008;2:100-102.

17. Tsymbalyuk I. Y., Manuilov A. M., Popov K. A., Basov A. A. Metabolic correction of the ischemia-reperfusive injury with sodium dichloroacetate in vascular isolation of the liver in experiment. Novosti Khirurgii. 2017;25(5):447453.

18. DiMarco T., Giulivi C. Current analytical methods for the detection of dityrosine, a biomarker of oxidative stress, in biological samples. Mass. Spectrom. Rev. 2007;26(1):108-120. https://doi.org/10.1002/mas.20109 


\title{
About authors:
}

Bykov Ilia Mikhaylovich, MD, PhD, Professor, Head of the Department of Fundamental and Clinical Biochemistry;

tel.: +79182125530; e-mail: ilya.bh@mail.ru

Popov Konstantin Andreevich, PhD, Assistant; tel.: +79288824941; e-mail: naftalin444@mail.ru

Berberidi Hristina Panaetovna, Post-graduate student; tel.: +79189045555; e-mail: hristy@mail.ru

Tsymbalyuk Igor Yuryevich, Laboratory assistant in the Department of Surgery № 2; tel.: +79284300769; e-mail: igor_ts@inbox.ru

Ermakova Galina Alekseevna, PhD, Assistant in the Department of Psychiatry; tel.: +79182125530; e-mail: ilya.bh@mail.ru

Pavlyuchenko Ivan Ivanovich, MD, PhD, Professor, Head of the Department of Biology; tel.: +79183668281; e-mail: pavluchenkoii@ksma.ru Storozhuk Petr Grigorievich, MD, PhD, Professor of the Department of Fundamental and Clinical Biochemistry;

tel.: +78612680230; e-mail: ilyaMB@ksma.ru

Ovsyannikov Viktor Grigorievich, MD, PhD, Professor, Head of Department of Pathophysiology;

tel.: +78632014412; e-mail: ovsyannikov_vg@mail.ru

(C) Group of authors, 2018

UDC 615.28

DOI - https://doi.org/10.14300/mnnc.2018.13093

ISSN - 2073-8137

\section{EFFECT OF NIOSOMAL ANTIMICROBIAL PEPTIDE hBD-1 ON THE HEALING RATE OF INFECTED WOUNDS IN RATS}

\author{
Bolatchiev A. D. ${ }^{1}$, Baturin V. A ${ }^{1,2}$, Bazikov I. A. ${ }^{1}$, Maltsev A. N. ${ }^{1}$
}

${ }^{1}$ Stavropol State Medical University, Russian Federation

2 Center of Clinical Pharmacology and Pharmacotherapy, Stavropol, Russian Federation

\section{ВАИЯНИЕ НИОСОМААЬНОГО АНТИМИКРОБНОГО ПЕПТИАА һВD-1 НА СКОРОСТЬ ЗАЖИВАЕНИЯ ИНФИЦИРОВАННЫХ РАН У КРЫС}

\author{
А. А. Болатчиев ', В. А. Батурин ${ }^{1,2}$, И. А. Базиков ${ }^{1}$, А. Н. Мальцев ${ }^{1}$ \\ 1 Ставропольский госуАарственный меАицинский университет, \\ Российская Фелерация \\ 2 Центр кАинической фармакологии и фармакотерапии, Ставрополь, \\ Российская Фелерация
}

In this study we investigated the effect of an antimicrobial peptide hBD-1 capsulated in organosilicon nanocontainers (niosomes) on the healing rate of experimental wounds infected with the clinical strain of Staphylococcus aureus. It was shown that the niosomal gel containing recombinant hBD-1 $(1 \mu \mathrm{g} / \mathrm{ml})$ increases the linear healing rate of infected wounds in rats compared to the control group.

Keywords: antimicrobial peptide, defensin, niosome, antibiotic resistance, $h B D-1$

Определялось влияние антимикробного пептида из класса бета-дефензинов (hBD-1), инкапсулированного в кремнийорганические наноконтейнеры (ниосомы), на скорость заживления экспериментальных ран, инфицированных клиническим штаммом Staphylococcus aureus. Было показано, что ниосомальный гель, содержащий рекомбинантный hBD-1 (1 мкг/мл), увеличивал линейную скорость заживления инфицированных ран у крыс по сравнению с контрольной группой.

Ключевые слова: антимикробные пептиды, дефензины, ниосомы, антибиотикорезистентность, hBD-1

For citation: Bolatchiev A. D., Baturin V. A., Bazikov I. A., Maltsev A. N. EFFECT OF NIOSOMAL ANTIMICROBIAL PEPTIDE hBD-1 ON THE HEALING RATE OF INFECTED WOUNDS IN RATS. Medical News of North Caucasus. 2018;13(3):515517. DOI - https://doi.org/10.14300/mnnc.2018.13093

Для цитирования: Болатчиев А. Д., Батурин В. А., Базиков И. А., Мальцев А. Н. ВЛИЯНИЕ НИОСОМАЛЬНОГО АНТИМИКРОБНОГО ПЕПТИДА hВD-1 НА СКОРОСТЬ ЗАЖИВЛЕНИЯ ИНФИЦИРОВАННЫХ РАН У КРЫС. МеДИЦИНСКИЙ вестник Северного Кавказа. 2018;13(3):515-517. DOI - https://doi.org/10.14300/mnnc.2018.13093

hBD-1 - Human Beta-Defensin-1

EUCAST - European Committee on Antimicrobial Susceptibility Testing 